\title{
CORPORATE GOVERNANCE PRACTICES AT HIGHER EDUCATION INSTITUTIONS IN SOUTH AFRICA
}

\author{
Ben Marx \\ University of Johannesburg \\ benm@uj.ac.za
}

February 2007

\begin{abstract}
South Africa boasts a vibrant higher education sector, with more than a million students enrolled in its higher education institutions. These institutions constitute highly complex organisations, with many and varied stakeholders and with budgets running into hundreds of millions of rands. Sound management and strict adherence to corporate governance principles and practices are essential to the success of these institutions. This will include the establishment of a well-balanced, independent and diligent council, as well as properly constituted and effective sub-committees of council. Of these sub-committees, the audit and finance committees are sure to play a pivotal part in ensuring financial discipline and adherence to sound corporate governance principles and practices. The principal aim of this paper will be to focus on the basic governance-regulatory requirements of higher education institutions in South Africa, and to benchmark these requirements against the corporate governance principles and practices required by King II.
\end{abstract}

\section{Keywords:}

Higher education institution, corporate governance, higher education governance structure, audit committee, remuneration committee, executive remuneration. 


\section{INTRODUCTION}

South Africa boasts a vibrant higher education sector that provides world-class tuition and research opportunities to more than a million students enrolled in its 23 universities, universities of technology and many colleges. These institutions function autonomously by reporting to their own councils, rather than to government.

Throughout the last decade, student numbers in these institutions rose steadily from 473000 in 1993 to 564000 in 1999, finally to exceed the 1000000 in 2006. These institutions (like many of their counterparts in other countries) constitute highly complex organisations with many and varied stakeholders and with budgets running into hundreds of millions of rands. They are faced with many challenges, which, inter alia, include issues of gender, transformation of students and staff, funding and resources, research and teaching, governance and administration, as well as the growth in the local and international providers of private higher education (Subotzky, n.d.; Garson, n.d.). For this reason, sound management and strict adherence to tried-and-tested governance principles and practices are deemed essential to the success of these institutions.

The council is a key constituent in the governance structure of these higher education institutions and, as such, should comply with fundamental corporate governance principles and practices. These principles and practices will include the establishment of a well-balanced, independent and diligent council, as well as the establishment of properly constituted and effective sub-committees of council. Of these sub-committees, the audit and finance committees are sure to play a pivotal part in ensuring financial discipline and adherence to sound corporate governance principles and practices. Another contentious issue at higher education institutions is the remuneration of executive management. Adherence to sound corporate governance principles and practices, together with an effective, diligent and transparent human resources or remuneration committee of council, could, however, play an important part in ensuring that fair and equitable remuneration packages are paid to these executive managers.

\section{RESEARCH OUTLINE}

\subsection{Research methodology}

The research methodology followed here comprised a two-pronged approach:

- Firstly, a literature study was undertaken of the underlying issues around and the requirements regarding corporate governance at the higher education institutions of South Africa. The said study served as the basis for the formulation of questions (checklist issues) that were empirically tested and analysed, as stated below.

- Secondly, an empirical study of the said higher education institutions was conducted in terms of which first the websites of the higher education institutions concerned were inspected and analysed and, secondly, their financial statements. 


\subsection{Population used in the empirical study}

The population used in the empirical study consisted of the 23 higher education institutions listed on the website of the Council on Higher Education (CHE) as on 5 May 2006 (Council on Higher Education, 2006).

\section{OVERVIEW OF THE HIGHER EDUCATION LANDSCAPE IN SOUTH AFRICA}

\subsection{Political and socio-cultural developments}

Many political and socio-cultural issues and developments played a role in the formation and structuring of the South African higher education landscape. According to a research report prepared for the Council on Higher Education by Hall, Symes and Luescher (2002), early higher education institutions in South Africa were based on models from United Kingdom and Scottish universities. A further significant influence proved to be the early dissension about the medium of instruction, which led to a split between English- and Afrikaans-medium universities. This was followed by sharp divisions along racial and ethnic lines, with 11 higher education institutions being funded in apartheid-inspired homelands between 1959 and 1988 (Hall, et al., 2002:20).

In a study conducted by Cooper and Subotzky in 2001, as quoted by Hall, et al. (2002:20), entitled "The skewed revolution: trends in South African higher education, 1988-1998", the erstwhile 36 higher education institutions were divided into sub-categories, namely the four English-medium universities reserved for white students, the six Afrikaans-medium universities originally reserved for white students, the seven technikons reserved for white students, the six universities and five technikons located in apartheid homelands and reserved for African students, the two urban universities and two technikons reserved for Coloured and Indian students, the two "special-purpose" institutions reserved for black students and the two distance-education providers. It is obvious that these divisions made for a unique system inherited by the first democratically elected South African government in 1994.

Hall, et al. (2002:20-24) argue that, under the apartheid regime, the relationship between individual institutions and the state varied considerably. He is quoted as saying the following about the divisions of yesteryear:

\footnotetext{
"The ten universities initially reserved for white students enjoyed a considerable degree of autonomy and were funded with block grants, allocated on a formula basis of student enrolments, research outputs and a number of other factors. The four English-medium institutions in this group - the 'liberal universities' - emerged as centres of opposition to Apartheid policies and were subjected to comparatively little state interference as a consequence. The Afrikaans-medium universities were given equal freedom. In contrast, the six homeland universities were highly controlled regarding the appointment of teaching staff and the curriculum. Their budgets were line-item extensions of homeland-administration budgets. The technikon sector, in contrast again, was established to promote education and training and had a nationally controlled and synchronised curriculum, and weak or non-existent traditions of academic freedom."
}

Since 1994, however, the trend has been to realign and reintegrate the South African higher education institutions to and with their global counterparts, and this trend, in turn, triggered an avalanche of reports, among which the following:

- Green Paper on Higher Education Transformation, 1996 (Department of Education, 1996). 
- A Programme for the Transformation of Higher Education, 1997 (Department of Education, 1997).

- Higher Education Act 101 of 1997 (Republic of South Africa, 1997).

- National Plan for Higher Education, 2001 (Ministry of Education, 2001).

- Manual for Annual Reporting of Higher Education Institutions, 2001 (Department of Education, 2001).

- Research and Policy Report on Governance in South African Higher Education, 2002 (Hall, et al., 2002).

- Press Statement by the Minister of Education, Professor Kader Asmal, on the Transformation and Reconstruction of the Higher Education System, 2002 (Asmal, 2002).

- Regulations for Annual Reporting 2003 (Republic of South Africa, 2003).

The above reports gave rise to a higher education environment in terms of which institutions are governed by their respective councils, subject to the Higher Education Act and their own institutional statute. As such, councils are their highest decision-making body, responsible for the governance, quality, integrity, financial affairs, performance and reputation of each institution.

\section{CONTENTIOUS ISSUES AND CHALLENGES FACING HIGHER EDUCATION INSTITUTIONS IN SOUTH AFRICA}

Higher education institutions are complex organisations facing many challenges. These include (but are by no means limited to) the following.

\subsection{Financial limitations}

First and foremost, higher education institutions in South Africa face financial challenges as a result of rising costs and dwindling government subsidies. In a report compiled by the labour union Solidarity in 2006 (2006:2), the following findings of research reports compiled by the South African Universities Vice Chancellors' Association (SAUVCA) in 2004, as well as the Association of Commonwealth Universities regarding Academic Staff Salary Surveys for 20042005, were published:

\subsubsection{Government subsidies}

- There has been a decline, in real terms, in government subsidies for every year since 1985 and, in 1997/98, universities received only $65.6 \%$ of their anticipated subsidy, and by $2004 / 04$, this percentage had dwindled to a mere $53 \%$.

- Levels of indebtedness (bad debt) on the part of students are on the increase and, concomitant with this, the levels of indebtedness of some of the institutions.

- Dwindling government subsidies and increased levels of indebtedness have seriously compromised the ability of universities to meet their personnel costs. 


\subsubsection{Disparity between salaries of academics and employees in the private sector}

The SAUVCA Report (2004) states that it has long been known that salaries earned by academics do not compare favourably with those earned by private-sector employees, and that the former also increase at a slower rate than private-sector salaries. This, then, accounts for the everwidening gap in salaries, which may go a long way in explaining the high staff-turnover rate dogging tertiary institutions.

\subsubsection{Staff remuneration}

The research report of the Association of Commonwealth Universities (ACU, 2006), in which the remuneration of academic staff at 50 universities belonging to the Association was compared, noted the following findings (Solidarity, 2006:4):

- Out of the six countries surveyed for the study, the remuneration of South African academic staff is worst, barring one (Malaysian academics are worse off).

- All academic remuneration compares badly to that of the private sector.

- Fringe benefits at South African higher education institutions are no better than those offered by higher education institutions in other countries included in the study, and therefore cannot compensate for the disparities in remuneration.

The Solidarity Report also found staff turnover as a major problem at higher education institutions. It went on to argue that the high staff-turnover rate was not owing to staff moving from one tertiary institution to another, as, according to the report findings, $22 \%$ of the turnover resulted from emigration and from a substantial number of academics leaving tertiary institutions to join the private sector (Solidarity, 2006:4).

\subsection{Student admissions}

Student admissions are problematic and pose real challenges. These concerns are best voiced by Ludolf Botha, Director of Academic Support at Stellenbosch University, who states that the system should set admission criteria that are fair and would ensure that those learners who are university material get in. The system should, however, also be flexible enough to accommodate students from educationally disadvantaged backgrounds and diversity (Byrd, 2006:4).

\subsection{Increasing student fees}

One of the challenges for universities is to provide world-class teaching and research opportunities to their students at affordable fees. Increases in student fees are a very sensitive issue and could easily give rise to student protest and unrest (Dixon, 2006:4).

\subsection{Skills shortage}

South Africa is experiencing a serious skills shortage. The task of addressing this was recently given to our Minister of Education, Naledi Pandor, who has identified the pathway from school to workplace by providing the right skills and institutions as a priority. This will impact directly on higher education institutions (Paton, 2006:22). 


\title{
4.5 Governance structures and perceived governance effectiveness
}

Higher education institutions should not only be well governed but should also be seen to be well governed. This sentiment is best voiced by Meredith Edwards (n.d:3), who states as follows:

\begin{abstract}
"Universities are large and complex organisations dependent still on government (i.e., taxpayer) funds. A most important reason for putting governance arrangements of universities under scrutiny is that it is in the interest of the long-term future of the university sector that universities are not only operating effectively but are seen to be doing so (own emphasis), if the sector is to retain community and hence government support. Ultimately, the key challenge is to devise governance structures (that) assure a well-run and managed university, but which respect the need for academic independence and all that this properly entails."
\end{abstract}

\subsection{Senior-staff remuneration}

The remuneration of senior-executive management of higher education institutions in South Africa is an equally sensitive, highly publicised and contentious issue.

Higher Education South Africa (HESA), in their report entitled "Good Governance of Senior Remuneration in South African Higher Education", make the following observations regarding senior-staff remuneration (HESA, 2006:1):

- Firstly, vice chancellors and senior staff in publicly funded institutions draw on the public purse for their remuneration. Remuneration levels, and the appropriateness of remuneration decisions, are a matter of interest to the government, Parliament and the broader society. Alongside institutional autonomy, public accountability is a cornerstone of the higher education policy framework in this country. The remuneration of senior staff in higher education should similarly be set and reviewed in line with the principles of effectiveness, efficiency and equity, and as appropriate to the social and public purposes of higher education in a developing economy.

- Secondly, remuneration is a matter of strategic importance for the higher education sector and for individual institutions. It enables institutions to attract and retain necessary qualities and skills for higher education leadership and optimum performance. Senior-staff remuneration decisions should enable institutional mission and strategy.

- Thirdly, in the present-day South African higher education sector, special emphasis is placed on the efficient use of public funds and the alternative sourcing of private funds in a climate of fiscal discipline. The remuneration of senior staff in higher education should be demonstrably affordable and sustainable, both at the individual institutional level and for the sector as a whole in the short, medium and long term. Remuneration decisions should extract value for money.

- Fourthly, good management practice in higher education is increasingly expected to align with good management practice in corporations. However, skills sets required of higher education executives (many of whom are by tradition academic leaders with little management experience or training) are changing, and remuneration levels will have to take cognisance of the complexity of the management task.

- Fifthly, it is evident from available data that there is wide-ranging disparity in the levels of remuneration paid to vice chancellors and senior staff at South Africa's universities and universities of technology, and that there is no obvious relationship between remuneration and factors such as size of institution, or institutional budget. 
Various negative press clippings follow every year after the filing of the financial statements of these institutions with the Department of Education (these are public documents open for scrutiny). The following are but two of them: "Varsity fat cats - vice chancellors at technikons and universities race to the top of the salary food chain" (Kyazze, 2006:7) and "Gravy-train academics could face pay cuts" (Naidu, 2006).

What these commentators seem to forget is that the demand for top-notch and experienced managers is fierce, and that these institutions must compete with the public sector for them. In order to attract top-class managers to manage their highly complex institutions, they should be willing and able to pay what is commensurate, or at least reasonably commensurate, to salaries offered by the private sector. The institutions that realise this will attract and retain world-class vice chancellors and deputy vice chancellors.

\section{OVERVIEW OF THE STATUTORY AND CORPORATE GOVERNANCE PRINCIPLES AND PRACTICES REGULATING HIGHER EDUCATION INSTITUTIONS}

\subsection{The concept of corporate governance}

Various definitions are used to elucidate the concept "corporate governance", of which the most appropriate are, arguably, those formulated in the King I (1994) and King II (2002) reports on corporate governance for South Africa:

King I (1994:1): "Corporate governance is described as simply the system by which companies are directed and controlled."

King II (2002:7): "Corporate governance is concerned with holding the balance between individual and communal goals... the aim is to align as nearly as possible the interests of individuals, corporations and society" (Sir Adrian Cadbury, Corporate Governance Overview, 1999, World Bank Report, as quoted in King II).

It is evident from the above definitions that good governance begins and ends with the board in other words, with the council of each higher education institution.

\subsection{Higher Education Act 101 of 1997}

The following two sections set out the governance requirements as required under the Act:

\section{Section 41. Records to be kept and information to be furnished by council}

(1) The council of a public higher education institution must, in the manner determined by the Minister, keep records of all its proceedings and must keep complete accounting records of all assets and liabilities, income and expenses, as well as any other financial transactions of the public higher education institution as a whole, of its substructures and of other bodies operating under its auspices.

(2) The council of a public higher education institution must, with respect to the preceding year and by a date or dates and in the manner determined by the Minister, provide the Minister with a report on the overall governance of the public higher education institution, a duly 
audited statement of income and expenditure and a balance sheet and cash-flow statement.

(3) The council of a public higher education institution must provide the Minister with such information, in such format, as the Minister may reasonably require.

\section{Section 60. Regulations}

The Minister may make regulations with this Act on any matter that the Minister is empowered or required to prescribe by regulation in terms of this Act and any other matter in respect of which the Minister deems it necessary or expedient to achieve the objects of this Act.

\subsection{Regulations for annual reporting by higher education institutions, 2003}

\subsubsection{Regulations}

The regulations prescribe the format, structure and content of the annual report and require the following:

- The reports and statements on governance and reports on operations.

- The report of the chairperson of the council.

- The council's statement on corporate governance.

- The senate's report to the council.

- The institutional forum's report to the council.

- The report of the principal on management and administration.

- The council's report on risk assessment and the management thereof.

- The audited annual financial statements, which must comply with South African Statements of Generally Accepted Accounting Practice (SA GAAP).

- Disclosure of remuneration of senior management.

\subsubsection{Manual}

The regulations include a manual that provides detailed guidance on the content of the reports. These guidelines are based on King II (2002). The most important requirements as per the manual are listed below:

- Council (King II:46-70) and the principal. The council and principal of a university or university of technology are responsible for ensuring that the business be conducted in an ethical manner that is economical, effective and efficient (own wording).

- Accountability (King II:7-120; 135-141)

- Compliance with the recommendations of the King Report on Corporate Governance for South Africa - 2002. The council must comply with the King II Report in respect of its governance, management and administration.

- Annual financial statements component of the annual report: compliance with South 
African Statements of Generally Accepted Accounting Practice (SA GAAP) (King II:42-45; 135-137). Note: Institutions were advised by the Department of Education in March 2006 that compliance with IFRS is voluntary and not encouraged. Institutions should rather comply with the South African Statements of Generally Accepted Accounting Practice (SA GAAP).

- Council (King II:22-26; 46-72)

- Comprises academic and non-academic persons of whom the majority (at least $60 \%$ ) should not be employees or students (non-executives).

- Chairman may not be the chief executive (non-executive chairman).

- Council should meet six times a year.

- Remuneration Committee (King III:26-28; 194-200). The Remuneration Committee must deal with rules relating to staff policies, remuneration, executive remuneration, members of Council remuneration and fees, service contracts and retirement funds.

- Finance Committee. The Finance Committee must recommend to Council the annual revenue and capital budgets and must monitor performance in relation to approved operating and capital budgets. It is responsible for assuring the financial health of the institution as a "going concern".

- Audit Committee (King II: 34-35; 68; 86-90; 186-194). The Audit Committee should consist of members of Council or of specialists in the field co-opted for their expertise. Meetings should be held at least twice a year and should be attended by internal and external auditors. The Committee should deal with
$\circ$ ensuring compliance with applicable legislation and the requirements of regulatory authorities
- matters relating to financial and internal control, accounting policies, reporting and disclosure
$\bigcirc \quad$ internal and external audit policies
- activities, scope, adequacy and effectiveness of the internal-audit function and audit plans
0 assessment of all areas of financial risk and the management thereof
- review/approval of external-audit plans, findings, problems, reports and fees
- compliance with the Code of Corporate Practices and Conduct
- compliance with the Code of Ethics of the institution.

\subsection{King II recommendations}

The King II Report on corporate governance specifies, inter alia, the following regarding board committees, audit committees and remuneration committees. These are included in the above recommendations of the manual. 


\subsubsection{Board committees}

King p.2.7.1 Board committees assist the board and the directors to discharge their duties and responsibilities. Boards cannot hide behind these committees.

King p.2.7.2 Formal procedures should exist for certain functions of the board to be delegated and the extent of delegation should be described to enable the board to properly to discharge its duties and responsibilities.

King p.2.7.3 Board committees should be formally defined in terms of reference, lifespan, role and functions and procedures, as well as written scope of authority.

King p.2.7.4 There should be transparency and full disclosure from the board's committees to the board.

King p.2.7.5 As a minimum, each board should have an audit and a remuneration committee, while industry and company issues will dictate the requirements for other committees.

King p.2.7.6 Non-executives must play an important role in board committees.

King p.2.7.7 Board committees should preferably be chaired by an independent, nonexecutive director.

King p.2.7.8 Board committees should be free to obtain independent, outside professional advice.

King p.2.7.9 In the annual report the committee composition, a brief description of its remit, the number of meetings held and other relevant information should be disclosed. Chairpersons of committees, particularly the audit, remuneration and nomination committees, should attend the company's AGM.

King p.2.7.10 Board committees should be subject to regular evaluation as to their performance and effectiveness.

\subsubsection{Audit committee}

King p.6.3.1 The board should appoint an audit committee with a majority of nonexecutive directors, of whom a sufficient number should be independent and the majority should be financially literate.

King p.6.3.2 The audit committee should select a chairperson who is an independent, non-executive director and who is not the chairperson of the board.

King p.6.3.3 The audit committee should have written terms of reference dealing with membership authority and duties.

King p.6.3.4 Companies should declare in the annual report whether or not the audit committee has adopted formal terms of reference, and if so, whether or not it is satisfied that it has complied with those terms of reference for the year. 
King p.6.3.5 Membership of the audit committee should be disclosed in the annual report. The chair should be available at AGMs to answer questions.

\subsubsection{Remuneration committee}

King p.2.5.2 Companies should appoint a remuneration committee consisting entirely or mainly of independent, non-executive directors, to make recommendations to the board within agreed terms of reference of the companies' framework of executive remuneration and to determine specific remuneration packages of executive directors, which is ultimately the responsibility of the board. This committee must be chaired by an independent, non-executive director.

King 2.5.4 Companies should provide full disclosure of directors' remuneration on an individual basis; and should give details of earnings, share options, restraint payments and other benefits.

King 2.5.2 Performance-related elements of remuneration should make up a substantial portion of executives' total remuneration package.

King 2.5.8 Overriding principle of full disclosure by all directors on an individual basis of share and other incentive schemes.

King 2.5.10 Formal and transparent procedures should exist for developing a policy on executive remuneration, supported by a statement on remuneration policy in the annual report.

\section{FINDINGS OF THE EMPIRICAL STUDY}

\subsection{Analysis of corporate governance disclosure on the websites}

The names of the 23 institutions whose websites were analysed are listed in Appendix A. These institutions were analysed in order to determine whether or not they disseminated or made available their information to users via a wide range of channels, as recommended by King II in par 6.2.6 (2002:39).

It is evident from TABLE 1 that the institutions in question do not fully disclose to their users their corporate governance information via a wide range of channels. It is recommended, therefore, that they update their websites and that they disclose all the information included in the annual reports (as discussed in par 5.3) submitted to the Department of Education, which reports are deemed public information. This will serve not only to enhance communication with their stakeholders (community, students, staff, etc.) but also the perceived integrity of their corporate governance principles and practices (as discussed in section 4.5). 
TABLE 1: Corporate governance disclosures

\begin{tabular}{|c|c|c|c|c|c|c|}
\hline & \multicolumn{2}{|c|}{ Total } & \multicolumn{2}{|c|}{ yes } & \multicolumn{2}{|c|}{ No } \\
\hline & Number & $\%$ & Number & $\%$ & Number & $\%$ \\
\hline Council disclosure & 23 & 100 & 18 & 78.2 & 5 & 21.8 \\
\hline $\begin{array}{l}\text { Corporate governance } \\
\text { disclosure }\end{array}$ & 23 & 100 & 3 & 13.0 & 20 & 87.0 \\
\hline Audit Committee disclosure & 23 & 100 & 2 & 8.7 & 21 & 91.3 \\
\hline $\begin{array}{l}\text { Remuneration Committee } \\
\text { disclosure }\end{array}$ & 23 & 100 & 1 & 4.3 & 22 & 95.7 \\
\hline $\begin{array}{l}\text { Finance Committee } \\
\text { disclosure }\end{array}$ & 23 & 100 & 2 & 8.7 & 22 & 91.3 \\
\hline
\end{tabular}

Source: Website disclosure

\subsection{Analysis of corporate governance disclosures in the 2006 annual reports}

The annual reports of the 23 universities and universities of technology for 2006 were inspected at the office of the Department of Education in Pretoria on 6 September 2006.

TABLE 2: Analysis of corporate governance disclosures in 2006 annual reports

\begin{tabular}{lcc}
\hline & Number & $\%$ \\
\hline Institution population & 23 & 100 \\
Number inspected & 17 & 73.9 \\
Not available on site on inspection date (Rhodes and Venda) & 2 & 8.7 \\
Not yet submitted (Cape Peninsula, Limpopo, Wits, Walter Sisulu) & 4 & 17.4 \\
\hline
\end{tabular}

Source: Annual report disclosure

In total, $73.9 \%$ of the institution population was analysed, which is deemed an appropriate and acceptable percentage from which to make meaningful deductions (please refer to Appendix A for a complete list of institutions).

\subsubsection{Council disclosure}

It is evident from the above TABLE 3 that the institutions in question comply with the requirements of King II listed under par 5.4, in terms of which the majority of board members should be non-executives (King, 2002:23), since 62.1\% (on average) of the council members are non-executive members of council. The chairs of council for all 17 institutions are also nonexecutive members, as required by King II. 
TABLE 3: Council disclosure

\begin{tabular}{lccccc}
\hline & Total & $\%$ & Total & $\begin{array}{c}\text { Average composition } \\
\text { Executive }\end{array}$ & Executive \\
\hline Non-disclosure of names & 5 & 29.4 & 29 & 18 & 11 \\
Disclosure of names & 12 & 70.6 & & $(62.1 \%)$ & $(37.9 \%)$ \\
& 17 & 100.0 & & & \\
Indication that chair of council & 17 & 100.0 & & & \\
is a non-executive & & & &
\end{tabular}

Source: Annual report disclosure

What is discouraging, however, is that 5 (or 29.4\%) of the institutions did not disclose the names and composition of their councils. This is contrary to the principles and practices of transparency and accountability of good corporate governance.

\subsubsection{Committee disclosure}

A close analysis of TABLE 4 highlights an alarming fact.

TABLE 4: Committee disclosures

\begin{tabular}{|c|c|c|c|c|c|c|}
\hline \multirow[b]{2}{*}{ Existence disclosed } & \multicolumn{2}{|c|}{ Audit Committee } & \multicolumn{2}{|c|}{$\begin{array}{l}\text { Remuneration or } \\
\text { HR Committee }{ }^{(1)}\end{array}$} & \multicolumn{2}{|c|}{$\begin{array}{l}\text { Finance } \\
\text { Committee }\end{array}$} \\
\hline & Total & $\%$ & Total & $\%$ & Total & $\%$ \\
\hline No & 3 & 17.6 & 2 & 11.8 & 4 & 23.5 \\
\hline yes & 14 & 82.4 & 15 & 88.2 & 13 & 76.5 \\
\hline Total & 17 & 100.0 & 17 & 100.0 & 17 & 100.0 \\
\hline $\begin{array}{l}\text { Composition and names } \\
\text { disclosed }\end{array}$ & 8 & 47.1 & 7 & 41.2 & 5 & 29.4 \\
\hline \multicolumn{7}{|c|}{$\begin{array}{l}\text { Average size and composition for } \\
\text { those disclosed }\end{array}$} \\
\hline Non-executives & 3 & 50.0 & 4 & 80.0 & 4 & 57.1 \\
\hline Executives & 1 & 16.7 & 1 & 20.0 & 3 & 42.9 \\
\hline Other & 2 & 33.3 & 0 & 0.0 & 0 & 0.0 \\
\hline Total & 6 & 100.0 & 5 & 100.0 & 7 & 100.0 \\
\hline
\end{tabular}

Source: Annual report disclosure

(1) Some institutions have separate remuneration and human resources committees. In such instances, special emphasis fell on the council committee dealing with executive remuneration and related issues. 
A number of the institutions surveyed do not disclose the existence of their audit committee ( 3 , or $17.6 \%)$, remuneration committee $(2$, or $11.8 \%)$ or finance committee $(4$, or $23.5 \%)$. It may be that such committees do not exist, which is contrary to King II, which requires at least an audit and a remuneration committee in paragraph 2.7.5.

It is even more alarming to find that even though the existence of such committees was acknowledged by a few institutions, very few actually disclosed any details about them, such as committee names and/or their compositions.

It is also interesting to note that six of the audit committees include members who are not council members, but experts in the study fields of auditing, accounting and law (this is in line with the recommendations of King $\mid \mathrm{I}$ and the Manual for Higher Education Institutions as discussed in paragraph 5.3.2).

\subsubsection{Accounting disclosure}

TABLE 5: Accounting disclosure

\begin{tabular}{lccc}
\hline & Financials prepared according to & Total & $\%$ \\
\hline IFRS & 2 & 11.8 \\
SA GAAP & 15 & 88.2 \\
Total & 17 & 100.0 \\
\hline
\end{tabular}

Source: Annual report disclosure

It was also interesting to note that two institutions (Stellenbosch University and Cape Town University) prepared their financial statements according to the International Financial Reporting Standards (IFRS). This was discouraged, albeit allowed, in a letter forwarded to the chief financial officers and auditors of these institutions by the Department of Education in March 2006, as stated in paragraph 5.3.2.

A possible explanation why these two institutions prepared their financial statements according to IFRS could be that they receive significant overseas funding, and therefore such institutions may be required to submit audited financial statements in line with IFRS.

\subsubsection{External-auditing disclosure}

It is evident from TABLE 6 that all the institutions are audited by four large audit firms, either independently or as joint auditors. This is owing to the fact that the auditing of such institutions is a complex and time-consuming affair, requiring a large number of staff members with the right levels of experience and expertise. 
TABLE 6: External auditing by firm

\begin{tabular}{lccccccc} 
& $\begin{array}{c}\text { Number } \\
\text { of } \\
\text { audits }\end{array}$ & Audit & $\begin{array}{c}\text { Average fee (Rand) } \\
\text { Other \& } \\
\text { consulting }\end{array}$ & Higher & Lower & Higher & Lower \\
\hline $\begin{array}{l}\text { Ernest \& Young } \\
\text { KPMG }\end{array}$ & 2 & 1630000 & 650000 & 1630000 & 1630000 & 650000 & 650000 \\
PWC & 3 & 726000 & 216000 & 1964000 & 214000 & 359000 & 59000 \\
Joint audits & 8 & 1137000 & 291000 & 1703000 & 774000 & 754000 & $0-$ \\
KPMG/SAB\&T & 2 & 1215000 & 1018500 & 2133000 & 297000 & 1663000 & 374000 \\
PWC/Gobodo & 1 & 474000 & 83000 & - & - & - & - \\
PWC/Ngubane & 1 & 1232000 & 70000 & - & - & - & - \\
\hline
\end{tabular}

Source: Annual report disclosure

(1) For Ernest \& Young, the data was only available for one of the two audits.

TABLE 7: Auditing fees

\begin{tabular}{lcc}
\hline \multicolumn{1}{c}{ Average fee } & $(R)$ & $\%$ \\
\hline Audit & 1097000 & $80.25 \%$ \\
Other \& consulting & 269999 & $19.75 \%$ \\
Total & 1366999 & $100 \% .00$ \\
\hline
\end{tabular}

Source: Annual report disclosure

The above fees appear to be very reasonable, given the complexity involved in auditing these institutions. The consulting and other fees as per the above table, however, are alarmingly high, which raises the question as to whether the significant scope of non-audit services provided to these institutions by the external auditors does not impact on their independence.

\subsubsection{Remuneration of executive management}

TABLE 8: Remuneration of executive management

\begin{tabular}{cccccc}
\hline & Vice chancellor & & \multicolumn{3}{c}{ Chief financial officer } \\
\hline Average & Highest & Lowest & Average & Highest & Lowest \\
\hline R1 700529 & R3 378000 & R954000 & R947 235 & Rl 676000 & R607 000 \\
\hline
\end{tabular}

Source: Annual report disclosure

As was pointed out in section 4.6, the remuneration of executive management or vice chancellors remains a highly contentious and hotly debated issue. Given the complexity, diversity and size of the institutions surveyed, however, the average remuneration paid to these 
executive managers appears fair and reasonable. This is based on the fact that the highest-paid vice chancellor received R3 378000 for 2006, whilst the highest-paid chief financial officer received Rl 676000 for the same period. In contrast with this, Johan van Zyl, the Chief Executive Officer of Sanlam (a large listed insurance company in South Africa) and erstwhile Vice Chancellor (Rector) of Pretoria University, received a salary package of R9 512000 for 2005, as per the latest available annual report (2005).

\section{CONCLUSION}

The principal aim of the paper was to provide an overview of the higher education landscape in South Africa, and to focus on a number of corporate governance problems and challenges facing the councils and sub-committees of councils in these institutions of higher learning, especially as adherence to sound corporate governance principles and practices is deemed a critical factor in the success of these institutions.

The research proved that the councils of the institutions surveyed appear to be well run and that, in general, they appear to be in compliance with the requirements of corporate governance as prescribed by King II. The research also brought to light, however, that many of the institutions surveyed could greatly benefit from improving their corporate governance disclosures, and by providing clear and detailed information on their websites, as well as in their annual reports, on their councils and sub-committees of councils. This will go a long way towards enhancing the integrity of these institutions as perceived by their various stakeholders.

Areas identified for further research include the relationship between the councils and their sub-committees, as well as the functioning of these committees. A further area for research would also be the formulation of criteria to be applied when determining executive management's remuneration in institutions of higher learning.

\section{REFERENCES}

Asmal. K. (2002). Press statement by the Minister of Education, Professor Kader Asmal, MP, on transformation and reconstruction of the higher education system, 30 May 2002. Available from: http://education.pww.gov.za/Media/Statements_2002/May02/he.htm (Accessed on 5 May 2006).

Association of Commonwealth Universities (ACU) (2004-2005). Academic-staff salary surveys.

Byrd, A. (2005). Making the cut. Financial Mail, FM Campus. 11 February 2005.

Council on Higher Education ( $\mathrm{CHE}$ ) (2006). Available from:

http://www.che.ac.za/links/links.php?cat=2 (Accessed on 5 May 2006).

Department of Education (1996). Green paper on Higher Education Transformation. Pretoria: Department of Education.

Department of Education (1997), A programme for the Transformation of Higher Education. Education White Paper 3, Government Gazette No 18207, 15 August 1997. Pretoria: Government Printers. 
Department of Education (2001). Manual for the Annual Reporting of Higher Education Institutions, $2^{\text {nd }}$ edition. (Revised draft.) Pretoria: Department of Education.

Dixon, B. (2005). Never enough. Financial Mail, FM Campus. 8 February 2005.

Edwards, M. (n.d.). University Governance: a mapping and some issues. Available from: www.atem.org.au/downloads/pdf/Governance.pdf (Accessed on 5 May 2006).

Garson, P. (n.d.). Education in South Africa. South Africa Info. Available from: Available from: http://www/southafrica.info/ess_info/sa_glance/education/education.htm (Accessed on 5 June 2006).

Higher Education South Africa (HESA) (2006). Good governance of senior-staff remuneration in South Africa. Higher Education and Remuneration Report of the Independence Reference Group. Pretoria: HESA.

Hall, M., Symes, A. \& Luescher, T.M. (2002). Governance in South African Higher Education. Research report prepared for the Council of Higher Education. Pretoria: HESA.

King Committee on Corporate Governance (King I Report) (1994). King Report on Corporate Governance. Johannesburg: Institute of Directors in Southern Africa.

King Committee on Corporate Governance (King II Report) (2002). King Report on Corporate Governance for South Africa. Johannesburg: Institute of Directors in Southern Africa.

Kyazze, S. (2006). Varsity fat cats. Financial Mail, FM Campus. 11 August 2006.

Ministry of Education. (2001). National Plan for Higher Education. Pretoria: Department of Education.

Naidu, દ. (2006). Gravy-train academics could face pay cuts. Sunday Independent. 30 April 2006. Available from:

http://www/iol.co.za/index.php?set_id=1\&click_id=13\&art_id=vn20060430083309536C230245 (Accessed on 7 May 2006).

Paton, C. (2005). Pandor to plug gaps. Financial Mail. 18 February 2005.

Republic of South Africa (1997). Higher Education Act No 101 of 1997. Government Gazette No 18515, Notice 1655, 19 December 1997. Pretoria: Government Printers.

Republic of South Africa (2003). Regulations for Annual Reporting by Higher Education Institutions. Government Gazette No 25407, Volume 458, August 2003.

Subotzky, G. (n.d.). Country Higher Education Profiles. INHEA. Available from: http://www.bc.edu/bc_org/avp/soe/cihe/inhea/profiles.South_Africa.htm. (Accessed on 19 September 2006).

Solidarity (2006). Tertiary institutions in South Africa: what is the current picture? Unpublished report. 
Appendix A: Names of higher education institutions inspected

\begin{tabular}{|c|c|c|c|}
\hline & Name of higher education institution & $\begin{array}{l}\text { Website } \\
\text { analysed }\end{array}$ & $\begin{array}{l}\text { Financials } \\
\text { inspected }\end{array}$ \\
\hline 1. & Cape Peninsula University of Technology & Yes & (1) \\
\hline 2. & Central University of Technology - Free State & Yes & yes \\
\hline 3. & Durban University of Technology & Yes & Yes \\
\hline 4. & Mangosuthu Technikon & yes & yes \\
\hline 5. & Nelson Mandela Metropolitan University & yes & yes \\
\hline 6. & North West University & yes & yes \\
\hline 7. & Rhodes University & yes & (2) \\
\hline 8. & Stellenbosch University & yes & yes \\
\hline 9. & Tshwane University of Technology & yes & Yes \\
\hline 10. & University of Cape Town & Yes & yes \\
\hline 11. & University of Fort Hare & yes & yes \\
\hline 12. & University of Johannesburg & yes & Yes \\
\hline 13. & University of KwaZulu-Natal & yes & yes \\
\hline 14. & University of Limpopo & yes & (1) \\
\hline 15 . & University of Pretoria & Yes & yes \\
\hline 16. & University of South Africa & yes & yes \\
\hline 17. & University of the Free State & yes & Yes \\
\hline 18. & University of the Western Cape & Yes & yes \\
\hline 19. & University of the Witwatersrand & yes & (1) \\
\hline 20. & University of Venda & yes & (2) \\
\hline 21. & University of Zululand & yes & yes \\
\hline 22. & Vaal University of Technology & yes & yes \\
\hline 23. & Walter Sisulu University of Technology \& Science & yes & (1) \\
\hline
\end{tabular}

Source: Annual report disclosure

(1) Not yet submitted.

(2) Not available on-site (at merger office) on the date of inspection. 